\title{
Motivational factors of pro-environmental behaviors among information technology professionals
}

Adedapo Oluwaseyi Ojo ( $\nabla$ ojo.adedapoolu@gmail.com )

Multimedia University https://orcid.org/0000-0002-9948-8733

\section{Research Article}

Keywords: Autonomous motivation, Controlled motivation, Self Determination Theory, Green HRM practices, Pro-environmental behavior, Green Information Technology

Posted Date: July 12th, 2021

DOl: https://doi.org/10.21203/rs.3.rs-683468/v1

License: (9) This work is licensed under a Creative Commons Attribution 4.0 International License. Read Full License 


\section{Abstract}

Following research on the significance of employees' behaviors in a firm's environmental initiatives, this study explores the motivational factors that influence information technology (IT) professionals' proenvironmental behaviors (PEBs). Based on the self-determination theory (SDT), autonomous and controlled motivations were posited as determinants of PEBs, and the green human resource management (GHRM) literature was integrated to examine the direct and indirect effects of GHRM practices. The hypothesized model was tested using data collected from 333 IT professionals in Malaysia. The results supported the view that autonomous motivation and GHRM practices have significant effects on PEBs. Furthermore, GHRM was a significant moderator of the effects of autonomous motivation on PEBs. On the contrary, the hypotheses that controlled motivation had a constraining effect, and GHRM has a moderating effect on PEBs were not supported. The present findings demonstrate that IT professionals' PEBs are associated with environmental practices based on interest and value. Thus, this study extends the SDT by incorporating GHRM literature to deepen the understanding of the motivational factors of PEBs among a sample of IT professionals.

\section{Introduction}

Many organizations have leveraged information technology (IT) in deploying seamless and efficient operations with minimal environmental impact (Przychodzen et al. 2018; Ojo et al. 2019; Muñoz-Pascual et al., 2021). However, the short lifespans of IT equipment and their manufacturing and disposal activities could contribute to environmental degradation. IT accounts for a large chunk of organizations' electricity costs, and its contributions to the carbon footprint have surpassed that of the aviation industry (Asadi et al. 2017). It is also forecasted to account for $20 \%$ of the global energy demand by 2025 , and by 2040 it will generate $14 \%$ of global carbon emissions (Vidal 2017). Hence, organizations have introduced several initiatives to support the transition to greener consumption and IT production to reverse this trend. Accordingly, the Green IT (GIT) domain has emerged within the broader information systems literature to deepen understanding of the adoption and outcomes of sustainable environmental practices in the IT life cycle (Melville 2010; Jenkin et al. 2011; Molla et al. 2014). GIT entails organizational intervention and behavioral changes among employees to ensure the sustainable design, manufacturing, usage, and disposal of IT devices with minimal or no effect on the environment (Murugesan 2008). A recent study from Stanford University on workstation power management revealed that the IT professionals' technology choice can account for between $17 \%$ and $74 \%$ drop in energy usage (Stanford). Hence, IT professionals play a critical role in the successful adoption of environmentally friendly workplace IT practices.

The GIT literature has increased rapidly in recent decades, with studies focusing on strategic implementation framework (Melville 2010; Jenkin et al. 2011), factors of adoption (Loeser et al. 2017), and critical success factors and benefits (Asadi et al. 2017; Przychodzen et al. 2018). Studies have also examined employees' adoption of environmental IT practices (Yoon 2018; Ojo et al. 2019). Nevertheless, recent studies have acknowledged the lack of adequate research on motivating employees' engagements 
in green initiatives (Elliot and Webster 2017; Ojo and Fauzi 2020). Davis et al. (2020) noted that further studies are necessary to enhance understanding of the mechanisms for motivating employees' engagement in pro-environmental behaviors (PEBs). PEBs are defined as "behaviors that employees engage in or bring about that are linked with, and contribute to, environmental sustainability" (Ones and Dilchert 2012, p. 456). Studies on green human resource management (GHRM) have demonstrated the relevance of environmentally oriented HRM practices in explaining the factors that affect employees' PEBs (Dumont et al. 2017; Tang et al. 2018; Fischer et al. 2019; Ojo et al. 2020). However, the GHRM literature is still in its infancy and further studies are needed to address the role of GHRM practices in motivating PEBs (Davis et al. 2020).

This study contributes to the literature by investigating the relationships between the motivational factors of PEBs and GHRM practices. This study aims to understand whether employees' PEBs are associated with self-directed motivation and the conditional effects of GHRM on PEBs. According to the selfdetermination theory (SDT), motivation can either be self-directed or controlled (Graves et al. 2019; Davis et al. 2020). Self-directed motivation is autonomously driven and activated when employees engage in PEBs out of their interest and love for nature. Employees' environmental behaviors could also be controlled by external rewards, such as the need for others' approval or avoidance of punishment. However, unlike autonomously motivated actions, controlled motivation is sustained by self-regulatory resources such as positive image and avoidance of punishment (Bolino 1999; Vohs et al. 2005). Thus, the underlying extrinsic motivation is derived by instrumentalities rather than enjoyment, which stimulate discretionary actions (Qiu et al. 2020). PEBs encompass complex and diverse issues that cannot be completely specified in job descriptions, and hence, the willingness to take voluntary actions is essential (Paillé et al. 2014; Ren et al. 2018). The present study examines the effects of self-directed and controlled motivation on PEBs.

Another key contribution of this study is the exploration into the direct and indirect effects of GHRM on PEBs (see Fig. 1). Previous studies have demonstrated the effects of GHRM practices on employees' ability and engagement in PEBs (Ren et al. 2018; Fawehinmi et al. 2020; Ojo et al. 2020). However, the effect of such practices on motivational factors has received limited attention (Li et al. 2020). The lack of focus on the motivational factors is consistent with HRM literature, where most organizational change initiatives are based on broader employee involvement (Renwick et al., 2013). As a result, the need to stimulate individuals' engagement has been overlooked in organization-based HRM interventions. By investigating employees' perception of GHRM practices, subsequent studies are poised to clarify the motivational factors that affect employees' discretionary environmental behavior (Ren et al. 2018). Thus, this paper seeks to deepen understanding of the motivational factors of PEBs by examining the moderating effect of GRHM practices on the relationship between motivation and PEBs.

The subsequent section presents the review of pertinent literature and hypotheses development, followed by methodology, results, discussions, and implications of findings, with recommendations for future studies. 


\section{Literature Review And Hypotheses Development}

\subsection{Self Determination Theory (SDT)}

SDT posits that the motivation underlying employees' engagement in job activities is an essential factor in their performance and wellness (Deci and Ryan 2017). The motivation to perform a specific action varies with the level of choice that an individual has over such action (Ryan and Deci 2000). Unlike extrinsic motivation, which is controlled by external factors, intrinsic motivation is autonomous and has been significantly associated with desirable behavior (Pelletier et al. 1998; Aitken et al. 2016).

SDT is relevant in explaining voluntary workplace behaviors that are not recognized nor specified directly in job descriptions but essential for organizational effectiveness (Gagné and Deci 2005). For example, employees may engage in required actions that earn rewards and in volitional actions, such as seeking a better understanding of the environment, championing sustainable initiatives, and facilitating colleagues' environmental behaviors. The voluntary activities are referred to as extra-role behaviors, which constitute PEBs and are deeply rooted in the concept of organizational citizenship behavior (OCB). According to Paillé et al. (2014), PEBs are complex and diverse, making them difficult to capture directly in job functions. Therefore, employees' willingness to take proactive actions is essential in addressing workplace environmental issues.

From the SDT perspective, voluntary workplace behaviors have been associated with altruistic or impression management purposes (Bolino 1999). Altruistically motivated behaviors are intrinsic and selfdetermined; thereby actions are based on personal interest and values (Aitken et al. 2016; Zhou 2016). For impression management, individuals are motivated to perform a particular behavior for personal gain or self-promoting purposes. Therefore, the underlying extrinsic motivation is associated with the opportunity to earn a good reputation when PEBs are influenced by feelings of shame and guilt (Jacquet 2015; Claeys 2020). Qiu et al. (2020) noted that individuals' feelings of shame could trigger actions based on concern and empathy, but it can also result in fatigue, undermining discretionary actions. Accordingly, autonomous and controlled motivations are proposed as determinants of PEBs.

\subsection{GHRM Practices}

GHRM stems from integrating environmental management systems (EMS) with HRM practices (González-Sánchez et al. 2018; Ojo and Raman 2019). The ISO 14001 is an example of an EMS and is a regulatory framework for documenting the procedures and policies that guide environmental practices across an organization's operations. The increasing awareness of sustainable environmental practices has hastened the organizations' adoption of GHRM practices. Through GHRM, the organizations can translate their environmental agenda into operational practices by aligning practices, such as training, performance management, recruitment, rewards, and compensation to environmental objectives (Tang et al. 2018; Ojo and Raman 2019). For example, the European electric utility company, E.ON's investment in educating its employees to switch off electrical devices when not in use has resulted in a savings of $€ 106,000$. Wal-Mart has also reported a saving of USD 12,000 through its paper-reduction usage 
campaign (Shoaib et al. 2021). In addition, a survey of multinational corporations has indicated the increasing adoption of GHRM practices as a mechanism to facilitate employees' engagement in PEBs (Frangieh and Yaacoub 2019).

Fundamental to the successful adoption of GHRM practices are employees involved directly in the operational activities and affected by the changes in the workplace (Ren et al. 2018; Ojo et al. 2020). Sustainable environmental practices extend beyond the required and rewarded behavior to include voluntary behavior, making employees' perception of GHRM critical. Consistent with the strategic HRM literature (Bowen and Ostroff 2004; Ngo et al. 2014), GHRM studies should emphasize the employees' perceptions and interpretations of the associated practices. This perspective is needed to deepen

understanding of the employees' cognitive and motivational processing of GHRM (Ren et al., 2018). Thus, building on the concept of GHRM attribution, this study explores IT professionals' response to GHRM practices aimed at supporting sustainable environmental management.

\subsection{Autonomous Motivation and PEBs}

Motivation is a salient determinant of human behavior expressed through goals, intense drive, and intentions. It is an essential element in ensuring that employees comply with sustainable initiatives. Therefore, organizations need to understand what motivates employees to align their interests with the overall strategic goals (Graves et al. 2019). Consistent with SDT, the underlying motivation for PEBs can be situated along a continuum based on the extent to which the behavior is self-determined (Koo and Chung 2014; Graves et al. 2019). The highest self-determination level is autonomous motivation, followed by controlled and amotivation (Deci and Ryan 1985; Ryan and Deci 2000). Autonomously motivated action is associated with intrinsic motivation and two other extrinsic motivation types, i.e., integrated and identified (Gagné and Deci 2005; Aitken et al. 2016). Although these three levels are theoretically distinct, they are all internally oriented, i.e., originating from within an individual. Not surprisingly, previous studies have found them highly related and have treated them as a single motivational factor, i.e., autonomous motivation (Ratelle et al. 2007; Koestner et al. 2008; Aitken et al. 2016).

Employees are autonomously motivated to perform PEBs when they consider the tasks challenging, exciting, and fun. Moreover, those who perform PEBs due to integrated or identified motivation have internalized the actions as personal. Internationalization is the "process of taking in values, beliefs, or behavioral regulations from external sources and transforming them into one's own" (Deci and Ryan 2017, p. 182). Therefore, autonomously motivated employees are expected to engage in IT PEBs because doing so aligns with their interests and inner values. Studies have reported higher task engagement levels and performance for internally motivated people driven by values and interests (Deci and Ryan 1985; Pelletier et al. 1998; Osbaldiston and Sheldon 2003). Thus, it is hypothesized that,

H1. Autonomous motivation is positively related to IT professionals' PEBs.

2.4 Controlled Motivation and PEBs

Page 5/26 
From the SDT perspective, human behavior can be controlled through introjected and externally regulated motivation (Deci and Ryan 2017). Introjection is a type of controlled motivation based on feelings of shame, guilt, or anxiety (Deci and Ryan 2017). According to Jacquet (2015), shame occurs when an individual associates others' opinions of his or her actions with a personal sense of worth. Guilt refers to an individual's perception of his or her action as nonconforming to acceptable norms. Shame and guilt can control behavior through the perception of failure to meet morally accepted standards. However, unlike shame, guilt is not equated with personal dignity or worth (Claeys 2020). Shame has also been considered counterproductive in stimulating behavioral change because its focus is on an individual's perception of self-worth as against the actual behavior (Claeys 2020). Meanwhile, feelings of shame can be constructive when it motivates action that reflects concern, generosity, empathy, and modesty.

People can participate in environmental actions when they perceive such actions as essential for demonstrating to others that they are concerned about the environment. Sexton and Sexton (2014) found that well-known hybrid car brands, such as the Toyota Prius recorded high sales in locations with environmentally friendly norms as compared to less recognized hybrid brands such as the Toyota Camry. In essence, people's engagement in environmental behaviors could be motivated externally when such actions are perceived as opportunities to earn a good reputation (Barclay and Barker 2020). An individual's feeling of shame and guilt could stimulate engagement in visible environmental initiatives for the sake of reputation. However, PEBs encompass both rewarded and unrewarded environmentally friendly actions, making the willingness to take discretionary actions an essential factor of such behaviors (Paillé et al. 2014; Ren et al. 2018).

Koestner (2008) noted that the effect of controlled motivation might be temporary unless the situational factors are available to facilitate desirable actions. Thus, controlled motivation is unlikely to stimulate the cognitive resources and concerted effort involved in taking discretionary actions like PEBs (Aitken et al. 2016). Rather, controlled behaviors are sustained when the possibility of receiving the desired outcome or avoiding an undesired one exists (Bolino 1999; Qiu et al. 2020). Qiu et al. (2020) demonstrated the significant effect of controlled motivation on citizenship fatigue, which undermines employees' engagement in discretionary actions. According to Graves et al. (2019), the rewards and punishment associated with controlled motivation could trigger feelings of pressure and coercion that could constrain employees' engagement in PEBs. In line with the above discussion, it is hypothesized that,

\section{H2. Controlled motivation is negatively related to IT professionals' PEBs.}

\subsection{GHRM Practices and PEBs}

The adoption of GHRM practices reflects an organization's commitment to preserving and managing the environment (Tang et al. 2018; Pham et al. 2019). Management commitment to the environment can be demonstrated through environmentally friendly policies, training, incentives, and strategies that focus on ensuring employees' involvement in environmental initiatives (Fawehinmi et al. 2020). GHRM practices include recruitment and selection, through which employees are selected for their green credentials. Nevertheless, recent studies have reported that green recruitment and selection are relevant at the initial 
stage. Other practices like training and empowerment are significant predictors of PEBs after joining the organization (Ojo et al., 2020; Pham and Paillé, 2019). Green training enables employees to appreciate the organization's environmental commitment and gain relevant knowledge, thereby enhancing their decision-making skills on complex environmental issues (Govindarajulu and Daily 2004). Hence, the bundle of GHRM practices is essential in stimulating employees' PEBs.

Rewards and performance management systems could motivate employees to apply their acquired skills and knowledge in the workplace. A rewards system can be enhanced when the appropriate performance metrics are assigned to assess employees' PEBs (Ojo et al., 2020). Furthermore, by involving employees in environmental initiatives, organizations create opportunities for those directly involved in the operations to contribute to environmental management (Renwick et al. 2013). The organization acknowledges the need for their input by allowing employees to shape environmental objectives, thereby encouraging them to contribute towards sustainable outcomes (Ojo and Raman 2019; Fawehinmi et al. 2020). The involvement of employees in developing and implementing environmental initiatives can facilitate commitment towards environmentally responsible decisions (Masri and Jaaron 2017). Consistent with the above discussion, it is hypothesized that,

\section{H3. GHRM is positively related to IT professionals' PEBs.}

\subsection{Moderating effect of GHRM practices}

Employees' motivation can be enhanced when HRM practices are focused on satisfying their needs (Minbaeva 2008; Fischer et al. 2019). The need for competence can be satisfied by providing adequate training, which motivates higher performance by enhancing employees' capabilities to execute organizational goals (Renwick et al., 2013). As employees gain more awareness of the negative impacts of non-sustainable workplace practices, they could become more interested in taking the appropriate actions to curb the effects (Stern et al. 1993). Jenkin et al. (2011) concurred that green training deepens employees' awareness of environmental initiatives, reduces knowledge gaps, and facilitates attitudinal change towards GIT practices. For employees motivated by interest and values, green training could enhance their understanding of environmental practices, thereby deepening their engagement in such practices.

Moreover, HRM practices that focus on involvement could influence autonomous motivation by increasing employees' perception of control over assigned tasks. Employees involved in their organizational environmental initiatives are empowered to offer suggestions and feedback on performance. Empowered employees have the authority and autonomy to take appropriate actions on their assigned tasks (Spreitzer, 1995). Thus, empowerment is an effective mechanism for enhancing an individual's self-efficacy and motivation (Li et al., 2015). According to Liden et al. (2000), through empowerment, the organization enables the employees to take timely actions in a specific situation, while non-empowered employees feel helpless. Thus, empowered employees are likely to perceive their job as meaningful, thereby stimulating their interest in contributing to organizational initiatives. 
Similar to autonomous motivation, the effects of controlled motivation on behavior could be contingent on the organizational context and policies (Koestner et al., 2008). People are motivated to work when the appropriate rewards and incentives are applied. Consistent with the SDT, rewards could affect the extent to which behaviors are autonomously motivated. Positive feedback provides competence information, satisfying the recipient's basic psychological need for competence and enhancing intrinsic motivation (Deci et al., 2017). Besides, rewards could be applied as a control mechanism to ensure that people exhibit the desired behavior. However, people could perceive tangible rewards as controlling, thereby creating a sense of pressure, frustration, vulnerability, and constraining intrinsic motivation.

GHRM systems enable the organization to compensate employees for their engagement in PEBs. The rewards systems become more significant with the appropriate mechanism to regulate the level of compensation. The performance appraisal systems could be used to assess employees' engagement in PEBs and apply commensurate rewards for their performance (Ojo et al., 2020). Hence, the rewards and performance management systems could be applied as external regulators of controlled motivation. The effect of controlled motivation could be extended with the continuous application of relevant external factors (Koestner, Otis, Powers, Pelletier, \& Gagnon, 2008). Accordingly, controlled motivation is sustained when the employees are rewarded according to their engagement in PEBs. Based on the above, the following hypotheses are suggested.

H4a. GHRM practices moderate the effect of autonomous motivation on IT professionals' PEBs.

H4b. GHRM practices moderate the effect of controlled motivation on IT professionals' PEBs.

\section{Method}

\subsection{Subjects and procedure}

Data were collected from IT professionals working in IS014001 certified companies with multimedia super corridor (MSC) status in Malaysia. The MSC companies are medium- to large-sized organizations that develop or substantially depend on IT in their operations. Following previous studies, the data collection was restricted to organizations with IS014001 certification (Eltayeb et al. 2011; Priyankara et al. 2018). These organizations are expected to have deployed environmental initiatives, such as GHRM, which could enhance the prospect of collecting data from respondents that are well informed on workplace environmental IT practices. The selected companies were identified from the SIRIM's directory of IS014001 certified companies. Accordingly, the listed companies' HR units were contacted to seek their consent for employees' participation in the survey. After sending three remainders, 88 companies agreed to participate in the survey.

Based on the $\mathrm{G}^{\star}$ power software, the minimum sample size was computed following the criteria set by Cohen (1988), i.e., effect size $\left(f^{2}\right)=0.15$ and $\alpha=0.05$ and $\beta=0.20$. Given the five independent variables and three control variables, a minimum sample of 92 is required, which means that the study's sample size of 333 is adequate (see Fig. 2). From the 440 questionnaires sent, 335 were returned as completed, 
but after inspection, two questionnaires were eliminated due to missing values. Therefore, 333 questionnaires were used in the final analysis. A total of 224 respondents were males $(67.3 \%)$ and 109 females (32.7\%). Almost half of the respondents, i.e., 156 (46.8\%) are within the age groups of 25-34 years, and another $30 \%$ from the age groups of $35-44$ years, with only $8.7 \%$ older than 45 years. The respondents were highly educated: $90.7 \%$ had bachelor's degrees and $6 \%$ had graduate degrees. In terms of job positions, $43.3 \%$ were executive, $44.4 \%$ middle management, and $12.3 \%$ were from the top management levels.

\subsection{Measures}

The measurement scales were adapted from previous studies to suit the sustainable environmental management context. All items were based on the five-point Likert-type scale, with responses ranging from strongly disagree to strongly agree. Measurement items for intrinsic motivation, integrated motivation, introjected motivation, identified motivation, and external regulations were adapted from the environmental motivation scale (Pelletier et al. 1998). Following previous studies, the items of intrinsic (four items, $a=0.899$ ), integrated (four items, $a=0.923$ ), and identified motivation (four items, $a=0.882$ ) were considered as measures for autonomous motivation. Similarly, both introjected (three items, $a=$ 0.925 ) and external motivation (three items, $a=0.849$ ) were considered as measures for controlled motivation (Ratelle et al. 2007; Koestner et al. 2008; Aitken et al. 2016). Furthermore, GHRM practices were measured with five items adapted from Ojo and Raman (2019), and PEBs (7 items, $a=0.926$ ) were adapted from Paillé et al. (2014).

\subsection{Control variables}

Consistent with the literature, the respondents' demographics were considered as control variables (Graves et al. 2019; Li et al. 2020). Thus, the effects of educational level ( $1=$ diploma, $2=$ bachelor's degree, 3 = graduate degree), age (in years, with a mean of 33.67), and company tenure (in years, with a mean of 8.93) on PEBs were tested in the hypothesized model.

\section{Data Analyses And Results}

The variance-based partial least squares (PLS) technique was used to analyze the measurement and structural models (Ringle et al. 2015). Unlike covariance-based structural equation modeling (SEM), the PLS-SEM is a desirable technique for predicting exogenous variables based on revised measures (Peng and Lai 2012; Ojo and Fauzi 2020). Following the two-stage approach, the measurement model was initially evaluated to assess the validity and reliability of the main constructs. In the second stage, the hypothesized model was tested by assessing the structural model (Hair et al. 2017).

\subsection{Measurement Model}

The reliability and convergent validity of the measurement model were assessed based on the factor loadings, Cronbach alpha (a), composite reliability (CR), and average variance extracted (AVE) values. 
Table 1 shows that all the loadings were higher than the threshold value of 0.6 . Furthermore, consistent with the a's acceptable values, the $C R$ values of all the variables were above the recommended value of 0.7. Simultaneously, the AVEs exceeded the recommended value of 0.5 . Therefore, the measurement model satisfied the requirements for internal consistency and convergent validity (Hair et al. 2017).

Following Fornell and Larcker's (1981) recommendations, I assessed the discriminant validity by comparing the root-squared values of AVEs with the corresponding correlation coefficients. Table 2 shows the condition for discriminant validity was satisfied with the root-squared values of AVEs having higher values than the pair of correlation coefficients for the associated constructs.

Nevertheless, the reliability of Fornell and Larcker's measure of discriminant validity has been questioned, and the Heterotrait-Monotrait ratio of correlations (HTMT) has been suggested as a more accurate measure (Henseler et al. 2015). In line with the recommendations of Henseler et al. (2015), the HTMT ratios are lower than the threshold value, thereby confirming discriminant validity (see Table 3 ).

\subsection{Structural Model}

In evaluating the structural model, this study examined the values of the beta coefficients, t-statistics based on bootstrapping procedure with a resample of 5000 , coefficient of determination $\left(R^{2}\right)$, effect sizes $\left(\mathrm{f}^{2}\right)$, and predictive relevance $\left(\mathrm{Q}^{2}\right)$ (Hair et al. 2017). The output of the bootstrapping procedure (see Table 4) indicates that autonomous motivation was significantly related to PEBs $(\beta=0.199, p<0.05)$, thereby supporting $\mathrm{H} 1$. However, the hypothesized effects of controlled motivation on PEBs were not statistically significant $(\beta=-0.020, p>0.05)$. Therefore, $H 2$ was not supported. The data support GHRM practices' influence on PEBs $(\beta=0.329, p<0.05)$. Nevertheless, none of the hypothesized control variables was significantly related to PEBs. Accordingly, the sampled IT professionals' PEBs were not different across ages, educational levels, and length of working experiences in their respective organizations.

Consequently, $31.9 \%$ of the variance in PEBs (i.e., $\mathrm{R}^{2}=0.319$ ) was explained by autonomous motivation and GHRM practices. Consistent with Cohen's (1988) recommendation of 0.26 as the cut-off value for a moderate $\mathrm{R}^{2}$, the reported $\mathrm{R}^{2}$ value of 0.319 can be considered substantial. In addition to its statistical significance, the $\mathrm{f}^{2}$ values were examined to determine the effect sizes. According to Cohen's (1988) guidelines, 0.02 indicates a small effect size, while 0.15 and 0.35 correspond to moderate and large effect sizes, respectively. As shown in Table 4, autonomous motivation has a small effect size, with GHRM having a moderate effect size. The $\mathrm{Q}^{2}$ value of 0.202 also indicates that the structural model has substantial predictive relevance

\subsection{Moderating analysis}

The moderating effect of GHRM practices was analyzed using the PLS product-indicator approach. PLS provides a more accurate technique for estimating moderation effects by accounting for the error that could minimize the path estimates, thereby enhancing the validation of theories (Henseler and Fassott 2010; Ali et al. 2016). Table 4 shows that GHRM practices significantly moderated the relationship 
between autonomous motivation and PEBs $(\beta=0.166, p>0.05)$, thereby supporting $\mathrm{H} 4$. The interaction plot in Fig. 3 revealed that autonomous motivation is more associated with PEBs at a high level of GHRM practices. However, $\mathrm{H} 5$ was not supported, i.e., the estimated beta coefficient for the moderating effect of GHRM practices on controlled motivation was not statistically significant $(\beta=-0.020, p>0.05)$. Thus, GHRM practices appear to enhance the effects of personal interest and environmental values on PEBs, but not that of concerns for reputation and rewards.

\subsection{Common Method Bias}

Common method bias (CMB) is a significant limitation of analysis based on cross-sectional data collected from a single respondent. Accordingly, the present study followed the relevant procedural and statistical recommendations to minimize CMB's effect (Guide and Ketokivi 2015). For the procedural remedy, a cover letter was enclosed with each of the questionnaires. This letter stated the purpose of the survey and promised to guarantee the respondents' anonymity. Following Podsakoff et al. (2003), Harman's single factor test was performed to determine the statistical effect of CMB. The result reveals that the largest single factor accounts for $38.23 \%$ of the variance, lower than the suggested value of $50 \%$ (Podsakoff et al. 2003). Thus, CMB has not significantly affected the self-reported data.

\subsection{Robustness Checks}

The robustness of the results was assessed by conducting supplementary analyses to check the likely effects of nonlinearity and unobserved heterogeneity (Svensson et al. 2018; Sarstedt et al. 2020). Following Svensson et al. (2018), potential nonlinearities were tested by including three interaction terms to represent the quadratic effects of GHRM, autonomous, and controlled motivation on PEBs. Table 5 shows the bootstrapping results with 5000 samples (no sign changes), which reveal that neither of the nonlinear effects is significant. Thus, the tested linear effects model is robust.

The FIMIX-PLS procedure was conducted to test the presence of unobserved heterogeneity in the path model (Sarstedt et al. 2020). In line with Sarstedt et al. (2020), a one-segment solution was initially assumed, and the procedure was executed with the default settings for the stop criterion $\left(10^{-10}=1.0 \mathrm{E}-\right.$ 10), the maximum number of iterations (5000), and the number of repetitions (10). Thereafter, the maximum numbers of the segment were determined using the minimum sample size of 92 as obtained from the G-Power analysis. Given the final sample size of 333, this study considers two- and threesegment solutions. The fit indices for the subsequent analysis reveal an ambiguous outcome (see Table 6). According to Sarstedt et al. (2020), the segment with the lowest values of AIC3 and CAIC can be considered the appropriate solution. In this study, however, the AIC3 and CAIC values point to three segments and one-segment solutions, respectively. The BIC and $\mathrm{MDL}_{5}$ values suggest two-segment and one-segment solutions, while AIC4 points to three segment solutions. Consistently, all entropy values are below the common threshold of 0.5 , indicating the absence of unobserved heterogeneity (Svensson et al. 2018). 


\section{Discussion}

This study contributes to the literature by drawing on the SDT to explore the potential effects of autonomous motivation and controlled motivation on IT professionals' PEBs. It also empirically demonstrates the significance of IT professionals' perceptions of GHRM practices by investigating the direct and indirect effects of GHRM on PEBs (Ren et al., 2018). Therefore, this study addresses the recent calls for further research on the situational factors of self-directed motivation (Davis et al., 2020; Deci and Ryan 2017; Fischer et al. 2019) by demonstrating the moderating effect of GHRM practices on the relationship between autonomous motivation and PEBs. In terms of the motivational determinants of PEBs, the data support the significant effect of autonomous motivation, but controlled motivation's negative effect was not supported. Thus, these results indicate that PEBs are associated with selfdetermined motivation, but not controlled motivation. Besides, GHRM was a significant predictor of PEBs and moderator for the effects of autonomous motivation on PEBs. However, the moderating effect of GHRM practices was not supported for controlled motivation. Therefore, $\mathrm{H} 1, \mathrm{H} 3$, and $\mathrm{H} 4$ were supported, but not $\mathrm{H} 2$ and $\mathrm{H} 5$. The main implications of these findings are discussed as follows.

The significant relationship between autonomous motivation and PEBs is consistent with previous studies, demonstrating that people engage in PEBs out of intrinsic and altruistic values (Aitken et al. 2016; Graves et al., 2019; Verplanken 2018). Autonomously motivated individuals consider their engagement in PEBs as an opportunity to do something of interest and value. Accordingly, employees who have internalized their interest and value for the environment are strongly inclined towards PEBs. The present finding demonstrates that discretionary actions, such as PEBs, can be influenced by internal motivation, enhancing individuals' commitment, persistence, and performance.

Contrary to expectation, the constraining influence of controlled motivation on employees' engagement in PEBs was not supported. The negative effect of controlled motivation manifests through external and introjected regulations. Employees' behaviors are externally controlled through rewards and threats, but these may constrain behaviors in the long term. Introjected motivation is regulated by concerns for reputation and recognition, which, when not satisfied, could trigger avoidance of the desired behaviors. Thus, motivation contingent on external rewards and concern for personal reputation is detrimental to persistent effort and task engagement. However, this negative effect was not observed in the present study. The lack of support is in tandem with previous findings on the effects of controlled motivation on personal goal progress (Judge et al. 2005; Koestner et al. 2008). Judge et al. (2005) noted that goals based on introjected regulation could be motivating but may not necessarily influence actions. Introjected goals could be masked by the lack of personal commitment, in which actions are shaped by the selfimposed pressures of shame or pride. Moreover, externally regulated goals might not influence actions because the rewards are not desirable. Hence, the negative influence of controlled motivation could be weakened when the PEBs are not perceived as obligatory or rewarding to necessitate actions.

As expected, GHRM practices were significantly related to PEBs. This result aligns with existing literature on the importance of GHRM practices in the firm's environmental management initiatives (Renwick et al. 
2013; Dumont et al. 2017; Ojo and Raman 2019). The present finding is also consistent with the HRM literature, which acknowledges that the employees' behaviors are influenced by their HRM practices' attributions (Bowen and Ostroff 2004; Nishii et al. 2008). The employees perceived the bundle of GHRM practices as the platform for creating environment-friendly policies, training, incentives, and strategies, influencing their engagement in PEBs. When knowledgeable employees are involved in environmental initiatives, they feel empowered through their autonomy to shape their firm's processes and operations, encouraging them to take appropriate actions to minimize environmental degradation (Renwick et al., 2013; Ojo and Raman, 2019). Thus, this study demonstrates the relevance of the HRM attribution concept in the GHRM domain.

Furthermore, the significant moderation of GHRM practices on the relationship between autonomous motivation and PEBs offers empirical support for the proposition by Bowen and Ostroff (2004) on the influence of HRM practices in motivating employees to adopt the desired behaviors. The bundle of GHRM practices could interact with self-determined motivation to facilitate employees' PEBs. The autonomously motivated employees tend to engage more in PEBs when the appropriate GHRM practices are deployed to enhance their competencies and autonomy. Employees' competence can be enhanced through training and performance appraisal, while green empowerment is essential to facilitating their sense of autonomy. Thus, employees who have satisfied their basic psychological needs (i.e., autonomy, competence, and relatedness) are more likely to engage in autonomous motivated behavior (Ryan \& Deci, 2000).

Controlled motivation is contingent on external rewards and concern for recognition; thus, GHRM practices were hypothesized as instrumental factors of PEBs. However, such practices do not appear to influence PEBs among externally and introjected motivated employees. Controlled motivation is more likely to regulate human behaviors when the interventions are desirable (Koestner et al. 2008). Nonautonomous behaviors are motivated by egoistic values, which stimulate one to engage in impression management purposes. Individuals who are ego involved are externally stimulated and seek to demonstrate their competencies relative to others (Ryan and Deci 1989). For these individuals, involvement in PEBs could be attributed to their expectations for rewards or self-promotion. The employees may not have perceived the GHRM practices measured in this study as essential to their needs. This proposition aligns with previous studies that revealed the significant effect of controlled motivation on required PEBs (Gagné and Deci 2005; Norton et al. 2015; Tian et al. 2020). According to Norton et al. (2015), external regulation is more likely to stimulate employees' engagement in the required and rewarded environmental practices. Employees are more likely to engage in such behaviors when they perceive that a desirable outcome is contingent on performance (Gagné and Deci 2005).

\subsection{Practice Implications}

This study offers suggestions to organizations on how to facilitate IT professionals' engagement in PEBs. The significant effect of autonomous motivation suggests the need for the organization to create enabling conditions for employees to develop interests in and value sustainable practices. Such conditions could be created through GHRM practices aligning with satisfying the employees' needs for 
competence, relatedness, and autonomy. Organizations can create a sense of ownership among the employees by involving them in environmental initiatives, thereby encouraging them to perform voluntary environmental actions. PEBs encompass a variety of activities that cannot be wholly captured in organization policies or job descriptions. Thus, employees who are given autonomy over their behaviors are more likely to demonstrate commitment towards such actions. Similarly, organizations should provide adequate environmental training to the employees to equip them with relevant environmental knowledge, which could support their IT PEBs.

Most organizations focus on product and quality metrics that are directly related to performance. Thus, the employees are pressured to align their involvement in activities associated with these metrics but not environmental practices (Haddock-Millar et al. 2016). Thus, to stimulate employees' engagement in environmental practices, the organizations must ensure that the relevant practices are captured in the metrics underlying performance. The organization could raise the importance of sustainable practices among the employees by aligning key performance indicators to environmental impact reduction, thereby stimulating their engagement in PEBs.

\section{Conclusion And Future Research}

The present study has empirically demonstrated the integration of SDT with GHRM practices in explaining PEBs among IT professionals. Notwithstanding the contributions of this study, there are few limitations that could be addressed in future studies. First, the use of cross-sectional data makes the present study susceptible to $\mathrm{CMB}$. Although the relevant procedural and statistical remedies have been considered, the issue with $\mathrm{CMB}$ can be addressed adequately by collecting data from multiple respondents. Hence, future studies are encouraged to collect data on GHRM practices from the HR personnel. Second, the use of longitudinal data is also suggested as an area of future research because it may clarify the causal relationship between motivational factors and PEBs. The causal effect can also be enhanced by replacing the self-reported IT PEBs with actual behavioral measures. Lastly, the lack of support for controlled motivation should be explored further by investigating the specific effects of autonomous and controlled motivation on voluntary and required PEBs.

Note: * (Control Variables); NA (Not Applicable); BCA Cl (bias-corrected accelerate confidence interval)

Note: $\mathrm{BCA} C \mathrm{Cl}$ (bias-corrected accelerate confidence interval)

Note: NA (Not Applicable); numbers in bold indicate the best outcome per segment criterion retention

\section{Declarations}

\section{Funding:}

Not Applicable 


\section{Conflicts of interest/Competing interests:}

Not Applicable

\section{Authors' contributions:}

The entire manuscript was prepared by the main author

\section{Acknowledgments:}

None

\section{References}

Aitken NM, Pelletier LG, Baxter DE (2016) Doing the difficult stuff: Influence of self-determined motivation toward the environment on transportation proenvironmental behavior. Ecopsychology 8:153-162. https://doi.org/10.1089/eco.2015.0079

Ali F, Kim WG, Ryu K (2016) The effect of physical environment on passenger delight and satisfaction: Moderating effect of national identity. Tour Manag 57:213-224.

https://doi.org/10.1016/j.tourman.2016.06.004

Asadi S, Hussin ARC, Dahlan HM (2017) Organizational research in the field of Green IT: A systematic literature review from 2007 to 2016. Telemat Informatics. https://doi.org/10.1016/j.tele.2017.05.009

Barclay P, Barker JL (2020) Greener Than Thou: People who protect the environment are more cooperative, compete to be environmental, and benefit from reputation. J Environ Psychol 72:101441. https://doi.org/10.1016/j.jenvp.2020.101441

Bolino M (1999) Citizenship and impression management: Good soldiers or good actors. Acad Manag Rev 24:82-98

Bowen DE, Ostroff C (2004) Understanding HRM-firm performance linkages: The role of the "strength" of the HRM system. Acad Manag Rev 29:203-221. https://doi.org/10.5465/AMR.2004.12736076

Claeys M (2020) Green shame: The next moral revolution? Glob Discourse 10:259-271. https://doi.org/10.1332/204378919X15764490951187

Cohen J (1988) Statistical Power Analysis for the Behavioral Sciences, 2nd edn. Routledge Davis MC, Unsworth KL, Russell S V., Galvan JJ (2020) Can green behaviors really be increased for all employees? Trade-offs for "deep greens" in a goal-oriented green human resource management intervention. Bus Strateg Environ 29:335-346. https://doi.org/10.1002/bse.2367 
Deci EL, Olafsen AH, Ryan RM (2017) Self-Determination Theory in Work Organizations: The State of a Science. Annu Rev Organ Psychol Organ Behav 4:19-43. https://doi.org/10.1146/annurev-orgpsych032516-113108

Deci EL, Ryan RM (2017) Self-Determination Theory: Basic Psychological Needs in Motivation Development and Wellness. Guilford Press, New York

Deci EL, Ryan RM (1985) Intrinsic motivation and self-determination in human behavior. Springer US, Boston, MA

Dumont J, Shen J, Deng X (2017) Effects of green HRM practices on employeee workplace green behavior: The role of psychological green climate and employee green values. Hum Resour Manage 56:613-627. https://doi.org/10.1002/hrm.21792

Elliot S, Webster J (2017) Editorial: Special issue on empirical research on information systems addressing the challenges of environmental sustainability: an imperative for urgent action. Inf Syst $\mathrm{J}$ 27:367-378. https://doi.org/10.1111/isj.12150

Eltayeb TK, Zailani S, Ramayah T (2011) Green supply chain initiatives among certified companies in Malaysia and environmental sustainability: Investigating the outcomes. Resour Conserv Recycl 55:495506. https://doi.org/10.1016/j.resconrec.2010.09.003

Fawehinmi O, Yusliza MY, Mohamad Z, et al (2020) Assessing the green behaviour of academics: The role of green human resource management and environmental knowledge. Int $\mathrm{J}$ Manpow. https://doi.org/10.1108/IJM-07-2019-0347

Fischer C, Malycha CP, Schafmann E (2019) The influence of intrinsic motivation and synergistic extrinsic motivators on creativity and innovation. Front Psychol 10:1-15.

https://doi.org/10.3389/fpsyg.2019.00137

Fornell C, Larcker DF (1981) Evaluating structural equation models with unobservable variables and measurements error. J Mark Res 18:39-50

Frangieh CG, Yaacoub HK (2019) Socially responsible human resource practices: disclosures of the world's best multinational workplaces. Soc Responsib J 15:277-295. https://doi.org/10.1108/SRJ-112017-0226

Gagné M, Deci EL (2005) Self-determination theory and work motivation. J Organ Behav 26:331-362. https://doi.org/10.1002/job.322

González-Sánchez D, Suárez-González I, Gonzalez-Benito J (2018) Human resources and manufacturing: where and when should they be aligned? Int J Oper Prod Manag 38:1498-1518.

https://doi.org/10.1108/IJOPM-07-2017-0393 
Govindarajulu N, Daily BF (2004) Motivating employees for environmental improvement. Ind Manag Data Syst 104:364-372. https://doi.org/10.1108/02635570410530775

Graves LM, Sarkis J, Gold N (2019) Employee proenvironmental behavior in Russia: The roles of top management commitment, managerial leadership, and employee motives. Resour Conserv Recycl 140:54-64. https://doi.org/10.1016/J.RESCONREC.2018.09.007

Guide VD., Ketokivi M (2015) Notes from the editors: Redefining some methodological criteria for the journal. J Oper Manag 37:v-viii

Haddock-Millar J, Sanyal C, Müller-Camen M (2016) Green human resource management: A comparative qualitative case study of a United States multinational corporation. Int J Hum Resour Manag 27:192211. https://doi.org/10.1080/09585192.2015.1052087

Hair JF, Hult GTM, Ringle CM, Sarstedt M (2017) A primer on partial least squares structural equation modeling (PLS-SEM), 2nd edn. SAGE Publications, Thousand Oaks: California

Henseler J, Fassott G (2010) Testing moderating effects in PLS path models: An illustration of available procedures. In: Vinizi VE, Chin WW, Henseler J, Wang H (eds) Handbook of Partial Least Squares.

Springer, Heidelberg, Dordrecht, London, New York, pp 713-735

Henseler J, Ringle CM, Sarstedt M (2015) A new criterion for assessing discriminant validity in variancebased structural equation modeling. J Acad Mark Sci 43:115-135. https://doi.org/10.1007/s11747-0140403-8

Jackson SE, Renwick DWS, Jabbour CJC, Muller-Camen M (2011) State-of-the-art and future directions for green human resource management. Ger J Res Hum Resour Manag 25:99-116. https://doi.org/10.1688/1862-0000

Jacquet J (2015) Is Shame Necessary? New Uses for an Old Tool. Pantheon, New York

Jenkin TA, Webster J, McShane L (2011) An agenda for "Green" information technology and systems research. Inf Organ 21:17-40. https://doi.org/10.1016/j.infoandorg.2010.09.003

Judge TA, Erez A, Bono JE, Locke EA (2005) Core self-evaluations and job and life satisfaction: The role of self-concordance and goal attainment. J Appl Psychol 90:257-268. https://doi.org/10.1037/00219010.90.2.257

Koestner R, Otis N, Powers TA, et al (2008) Autonomous motivation, controlled motivation, and goal progress. J Pers 76:1201-1230. https://doi.org/10.1111/j.1467-6494.2008.00519.x

Koo C, Chung N (2014) Examining the eco-technological knowledge of Smart Green IT adoption behavior: A self-determination perspective. Technol Forecast Soc Change 88:140-155.

https://doi.org/10.1016/j.techfore.2014.06.025

Page 17/26 
Li W, Bhutto TA, Xuhui W, et al (2020) Unlocking employees' green creativity: The effects of green transformational leadership, green intrinsic, and extrinsic motivation. J Clean Prod 255:120229. https://doi.org/10.1016/j.jclepro.2020.120229

Li Y, Wei F, Ren S, Di Y (2015) Locus of control, psychological empowerment and intrinsic motivation relation to performance. J Manag Psychol 30:422-438. https://doi.org/10.1108/JMP-10-2012-0318

Liden RC, Wayne SJ, Sparrowe RT (2000) An examination of the mediating role of psychological empowerment on the relations between the job, interpersonal relationships, and work outcomes. J Appl Psychol 85:407-416. https://doi.org/10.1037/0021-9010.85.3.407

Loeser F, Recker J, Brocke J vom, et al (2017) How IT executives create organizational benefits by translating environmental strategies into Green IS initiatives. Inf Syst J 27:503-553. https://doi.org/10.1111/isj.12136

Masri HA, Jaaron AAM (2017) Assessing green human resources management practices in Palestinian manufacturing context: An empirical study. J Clean Prod 143:474-489.

https://doi.org/10.1016/j.jclepro.2016.12.087

Melville NP (2010) Information systems innovation for environmental sustainability. MIS Q 34:1-21

Minbaeva DB (2008) HRM practices affecting extrinsic and intrinsic motivation of knowledge receivers and their effect on intra-MNC knowledge transfer. Int Bus Rev 17:703-713.

https://doi.org/10.1016/j.ibusrev.2008.08.001

Molla A, Abareshi A, Cooper V (2014) Green IT beliefs and pro-environmental IT practices among IT professionals. Inf Technol People 27:129-154. https://doi.org/10.1108/ITP-10-2012-0109

Muñoz-Pascual L, Curado C, Galende J (2021) How does the use of information technologies affect the adoption of environmental practices in SMEs? A mixed-methods approach. Rev Manag Sci 15:75-102. https://doi.org/10.1007/s11846-019-00371-2

Murugesan S (2008) Harnessing Green It: Principles and Practices. IT Prof 10:24-33. https://doi.org/10.1002/9781118305393

Ngo HY, Jiang CY, Loi R (2014) Linking HRM competency to firm performance: An empirical investigation of Chinese firms. Pers Rev 43:898-914. https://doi.org/10.1108/PR-05-2013-0086

Nishii LH, Lepak DP, Schneider B (2008) Employee attributions of the "why " of HR practices: Their effects on employee attitudes and behaviors, and customer satisfaction. Pers Psychol 61:503-545

Norton TA, Parker SL, Zacher H, Ashkanasy NM (2015) Employee Green Behavior: A Theoretical Framework, Multilevel Review, and Future Research Agenda. Organ Environ 28:103-125. https://doi.org/10.1177/1086026615575773 
Ojo AO, Fauzi MA (2020) Environmental awareness and leadership commitment as determinants of IT professionals engagement in GreenIT practices for environmental performance. Sustain Prod Consum 24:298-307. https://doi.org/https://doi.org/10.1016/j.spc.2020.07.017

Ojo AO, Raman M (2019) Role of Green HRM Practices in Employees' Pro-environmental IT Practices. In: Rocha Á (ed) New Knowledge in Information Systems and Technologies. Springer, pp 678-688

Ojo AO, Raman M, Downe AG (2019) Toward green computing practices: A Malaysian study of green belief and attitude among Information Technology professionals. J Clean Prod 224:246-255. https://doi.org/10.1016/j.jclepro.2019.03.237

Ojo AO, Tan CNL, Alias M (2020) Linking green HRM practices to environmental performance through proenvironment behaviour in the information technology sector. Soc Responsib J. https://doi.org/10.1108/SRJ-12-2019-0403

Ones DS, Dilchert S (2012) Environmental Sustainability at Work: A Call to Action. Ind Organ Psychol 5:444-466. https://doi.org/10.1111/j.1754-9434.2012.01478.x

Osbaldiston R, Sheldon KM (2003) Promoting internalized motivation for environmentally responsible behavior: A prospective study of environmental goals. J Environ Psychol 23:349-357. https://doi.org/10.1016/S0272-4944(03)00035-5

Paillé P, Chen Y, Boiral O, Jin J (2014) The Impact of Human Resource Management on Environmental Performance: An Employee-Level Study. J Bus Ethics 121:451-466. https://doi.org/10.1007/s10551-013$1732-0$

Pelletier LG, Tuson KM, Green-Demers I, et al (1998) Why Are You Doing Things for the Environment? The Motivation Toward the Environment Scale (MTES)1. J Appl Soc Psychol 28:437-468.

https://doi.org/10.1111/j.1559-1816.1998.tb01714.x

Peng DX, Lai F (2012) Using partial least squares in operations management research: A practical guideline and summary of past research. J Oper Manag 30:467-480.

https://doi.org/10.1016/j.jom.2012.06.002

Pham NT, Hoang HT, Phan QPT (2019) Green human resource management: a comprehensive review and future research agenda. Int J Manpow. https://doi.org/10.1108/IJM-07-2019-0350

Podsakoff PM, MacKenzie SB, Lee J-Y, Podsakoff NP (2003) Common method biases in behavioral research: A critical review of the literature and recommended remedies. J Appl Psychol 88:879-903. https://doi.org/10.1037/0021-9010.88.5.879

Priyankara HPR, Luo F, Saeed A, et al (2018) How does leader's support for environment promote organizational citizenship behaviour for environment? A multi-theory perspective. Sustain 10:. https://doi.org/10.3390/su10010271 
Przychodzen W, Gómez-Bezares F, Przychodzen J (2018) Green information technologies practices and financial performance - The empirical evidence from German publicly traded companies. J Clean Prod 201:570-579. https://doi.org/10.1016/j.jclepro.2018.08.081

Qiu Y, Lou M, Zhang L, Wang Y (2020) Organizational citizenship behavior motives and thriving at work: The mediating role of citizenship fatigue. Sustain 12:. https://doi.org/10.3390/su12062231

Ratelle CF, Guay F, Vallerand RJ, et al (2007) Autonomous, controlled, and Amotivated types of academic motivation: A person-oriented analysis. J Educ Psychol 99:734-746. https://doi.org/10.1037/00220663.99.4.734

Ren S, Tang G, E. Jackson S (2018) Green human resource management research in emergence: A review and future directions. Asia Pacific J Manag 35:769-803. https://doi.org/10.1007/s10490-017-9532-1

Renwick DWS, Redman T, Maguire S (2013) Green Human Resource Management: A Review and Research Agenda. Int J Manag Rev 15:1-14. https://doi.org/10.1111/j.1468-2370.2011.00328.x

Ringle CM, Wende S, Becker J-M (2015) SmartPLS 3

Ryan RM, Deci EL (2000) Self-determination theory and the facilitation of intrinsic motivation, social development, and well-being. Am Psychol 55:68-78. https://doi.org/10.1037/0003-066X.55.1.68

Ryan RM, Deci EL (1989) Bridging the research traditions of task/ego involvement and intrinsic/extrinsic motivation: Comment on Butler (1987). J Educ Psychol 81:265-268. https://doi.org/10.1037//00220663.81.2.265

Sarstedt M, Ringle CM, Cheah JH, et al (2020) Structural model robustness checks in PLS-SEM. Tour Econ 26:531-554. https://doi.org/10.1177/1354816618823921

Sexton SE, Sexton A (2014) Conspicuous conservation: the prius halo and willingness to pay for environmental bona fides. J Environ Econ Manage 67:303-317

Shoaib M, Abbas Z, Yousaf M, et al (2021) The role of GHRM practices towards organizational commitment: A mediation analysis of green human capital. Cogent Bus Manag 8:. https://doi.org/10.1080/23311975.2020.1870798

Spreitzer GM (1995) Psychological empowerment in the workplace: Dimensions, measurement, and validation. Acad Manag J 38:1442-1465

Stanford Sustainable IT initiatives. In: Stanford Univ. https://sustainable.stanford.edu/sustainable-itinitiatives

Stern PC, Dietz T, Kalof L (1993) Value Orientations, Gender, and Environmental Concern. Environ Behav 25:322-348. https://doi.org/10.1177/0013916593255002 
Svensson G, Ferro C, Høgevold N, et al (2018) Framing the triple bottom line approach: Direct and mediation effects between economic, social and environmental elements. J Clean Prod 197:972-991. https://doi.org/10.1016/j.jclepro.2018.06.226

Tang G, Chen Y, Jiang Y, et al (2018) Green human resource management practices: scale development and validity. Asia Pacific J Hum Resour 56:31-55. https://doi.org/10.1111/1744-7941.12147

Tian H, Zhang J, Li J (2020) The relationship between pro-environmental attitude and employee green behavior: the role of motivational states and green work climate perceptions. Environ Sci Pollut Res 27:7341-7352. https://doi.org/10.1007/s11356-019-07393-z

Verplanken B (2018) Promoting Sustainability: Towards a Segmentation Model of Individual and Household Behaviour and Behaviour Change. Sustain Dev 26:193-205. https://doi.org/10.1002/sd.1694

Vidal J (2017) 'Tsunami of data' could consume one fifth of global electricity by 2025. In: Guard. http://www.climatechangenews.com/2017/12/11/tsunami-data-consume-one-fifth-global-electricity2025/. Accessed 21 Aug 2018

Vohs KD, Baumeister RF, Ciarocco NJ (2005) Self-regulation and self-presentation: Regulatory resource depletion impairs impression management and effortful self-presentation depletes regulatory resources. J Pers Soc Psychol 88:632-657. https://doi.org/https://doi.org/10.1037/0022-3514.88.4.632

Yoon C (2018) Extending the TAM for Green IT: A normative perspective. Comput Human Behav 83:129139. https://doi.org/10.1016/j.chb.2018.01.032

Zhou M (2016) Chinese university students' acceptance of MOOCs: A self-determination perspective. Comput Educ 92-93:194-203. https://doi.org/10.1016/j.compedu.2015.10.012

\section{Tables}

Table 1. Measurement Scales and Results of Measurement Model 


\begin{tabular}{|c|c|c|c|c|c|}
\hline Construct & Items & Loading & $\alpha$ & CR & AVE \\
\hline \multirow{13}{*}{$\begin{array}{l}\text { Autonomous } \\
\text { Motivation (Mean } \\
=3.600 ; \text { S.D. = } \\
0.688 \text { ) }\end{array}$} & I enjoy learning new ways to help & 0.606 & 0.936 & 0.941 & 0.577 \\
\hline & $\begin{array}{l}\text { the environment by engaging in } \\
\text { green behavior. }\end{array}$ & & & & \\
\hline & $\begin{array}{l}\text { It is my pleasure to improve the } \\
\text { quality of the environment by being } \\
\text { green. }\end{array}$ & 0.645 & & & \\
\hline & $\begin{array}{l}\text { I feel good when doing things for } \\
\text { the environment by engaging in } \\
\text { green behavior. }\end{array}$ & 0.583 & & & \\
\hline & $\begin{array}{l}\text { It is my pleasure to contribute to } \\
\text { protecting the environment by } \\
\text { engaging in green behavior. }\end{array}$ & 0.606 & & & \\
\hline & $\begin{array}{l}\text { Being green is an integral part of } \\
\text { my life. }\end{array}$ & 0.860 & & & \\
\hline & $\begin{array}{l}\text { Being green has become a } \\
\text { fundamental part of who I am. }\end{array}$ & 0.864 & & & \\
\hline & $\begin{array}{l}\text { Being green has been a part of the } \\
\text { way I've chosen to live my life. }\end{array}$ & 0.873 & & & \\
\hline & $\begin{array}{l}\text { By engaging in green behavior, I } \\
\text { take care of myself and the } \\
\text { environment. }\end{array}$ & 0.857 & & & \\
\hline & $\begin{array}{l}\text { Engaging in green behavior is a } \\
\text { sensible thing to do }\end{array}$ & 0.821 & & & \\
\hline & $\begin{array}{l}\text { Engaging in green behavior is a } \\
\text { way I've chosen to contribute to } \\
\text { protecting the environment. }\end{array}$ & 0.806 & & & \\
\hline & $\begin{array}{l}\text { Engaging in green behavior is a } \\
\text { reasonable thing to do. }\end{array}$ & 0.750 & & & \\
\hline & $\begin{array}{l}\text { Engaging in green behavior is good } \\
\text { thing to do. }\end{array}$ & 0.748 & & & \\
\hline \multirow{6}{*}{$\begin{array}{l}\text { Controlled } \\
\text { Motivation (Mean } \\
=3.642 ; \mathrm{SD}= \\
0.834)\end{array}$} & $\begin{array}{l}\text { I would regret it if I didn't engage in } \\
\text { green behavior. }\end{array}$ & 0.886 & 0.933 & 0.947 & 0.749 \\
\hline & $\begin{array}{l}\text { I would feel guilty if I didn't engage } \\
\text { in green behavior. }\end{array}$ & 0.881 & & & \\
\hline & $\begin{array}{l}\text { I would feel ashamed if I didn't } \\
\text { engage in green behavior. }\end{array}$ & 0.903 & & & \\
\hline & $\begin{array}{l}\text { My work requires engaging in } \\
\text { green behavior. }\end{array}$ & 0.879 & & & \\
\hline & $\begin{array}{l}\text { I would be rewarded for engaging } \\
\text { in green behavior. }\end{array}$ & 0.842 & & & \\
\hline & $\begin{array}{l}\text { I would be paid for engaging in } \\
\text { green behavior. }\end{array}$ & 0.797 & & & \\
\hline \multirow{4}{*}{$\begin{array}{l}\text { GHRM } \\
\text { Practices }(\text { Mean = } \\
\text { 3.338; SD = 0.771) }\end{array}$} & Our company provides & 0.791 & 0.812 & 0.869 & 0.571 \\
\hline & $\begin{array}{l}\text { environmental management } \\
\text { training for the employees. }\end{array}$ & & & & \\
\hline & $\begin{array}{l}\text { Employees contributions to } \\
\text { environmental management are } \\
\text { included in performance appraisal. }\end{array}$ & 0.759 & & & \\
\hline & $\begin{array}{l}\text { Employees are encouraged to } \\
\text { contribute to environmental } \\
\text { protection initiatives. }\end{array}$ & 0.787 & & & \\
\hline
\end{tabular}




\begin{tabular}{|c|c|c|c|c|c|}
\hline Construct & Items & Loading & $\boldsymbol{\alpha}$ & CR & $\overline{\text { AVE }}$ \\
\hline & $\begin{array}{l}\text { Employees suggestions for } \\
\text { innovative environmental initiative } \\
\text { are rewarded in our company. }\end{array}$ & 0.714 & & & \\
\hline & $\begin{array}{l}\text { Applicants' awareness about green } \\
\text { practices is an essential criterion in } \\
\text { selection. }\end{array}$ & 0.725 & & & \\
\hline \multirow[t]{7}{*}{$\begin{array}{l}\text { PEBs }(\text { Mean }= \\
\text { 3.724; } \mathrm{SD}=0.937)\end{array}$} & $\begin{array}{l}\text { I suggest workplace practices that } \\
\text { could improve Green IT } \\
\text { performance. }\end{array}$ & 0.761 & 0.925 & 0.940 & 0.692 \\
\hline & $\begin{array}{l}\text { I encourage my colleagues to adopt } \\
\text { Greener IT conscious behaviour. }\end{array}$ & 0.725 & & & \\
\hline & $\begin{array}{l}\text { I stay informed of my company's } \\
\text { Green IT efforts. }\end{array}$ & 0.850 & & & \\
\hline & $\begin{array}{l}\text { I make suggestions about ways to } \\
\text { protect the environment more } \\
\text { effectively. }\end{array}$ & 0.886 & & & \\
\hline & $\begin{array}{l}\text { I volunteer for projects or activities } \\
\text { that address Green IT issues in my } \\
\text { company. }\end{array}$ & 0.865 & & & \\
\hline & $\begin{array}{l}\text { I spontaneously give my time to } \\
\text { help my colleagues incorporate } \\
\text { Green IT into their job. }\end{array}$ & 0.853 & & & \\
\hline & $\begin{array}{l}\text { I undertake Green IT actions that } \\
\text { contribute positively to my } \\
\text { company's image. }\end{array}$ & 0.868 & & & \\
\hline
\end{tabular}

Table 2. Fornell and Larcker's Discriminant Validity Test Results

\begin{tabular}{lcccc}
\hline \multicolumn{1}{c}{ Constructs } & $\mathbf{1}$ & $\mathbf{2}$ & $\mathbf{3}$ & $\mathbf{4}$ \\
\hline 1. Autonomous Motivation & $\mathbf{0 . 7 5 9}$ & & & \\
2. Controlled Motivation & 0.759 & $\mathbf{0 . 8 6 5}$ & & \\
3. GHRM Practices & 0.434 & 0.286 & $\mathbf{0 . 7 5 6}$ & \\
4. PEBs & 0.412 & 0.335 & 0.487 & $\mathbf{0 . 8 3 2}$ \\
\hline
\end{tabular}

Table 3. Heterotrait-Monotrait Ratio of Correlations (HTMT)

\begin{tabular}{lccc}
\hline \multicolumn{1}{c}{ Constructs } & $\mathbf{1}$ & $\mathbf{2}$ & $\mathbf{3}$ \\
\hline 1. Autonomous Motivation & & & \\
2. Controlled Motivation & 0.788 & & \\
\hline 3. GHRM Practices & 0.468 & 0.318 & \\
\hline 4. PEBs & 0.378 & 0.353 & 0.552 \\
\hline
\end{tabular}


Table 4. Results of Hypotheses Testing

\begin{tabular}{|c|c|c|c|c|c|c|c|c|}
\hline $\mathrm{H}$ & Description & Beta & $\begin{array}{l}97.5 \% \\
\mathrm{BCA} \text { CI }\end{array}$ & $\begin{array}{c}\text { p- } \\
\text { value }\end{array}$ & $\mathrm{f}^{2}$ & Result & $\mathrm{R}^{2}$ & $\overline{Q^{2}}$ \\
\hline $\mathrm{H1}$ & $\begin{array}{l}\text { Autonomous Motivation } \\
\rightarrow \text { PEBs }\end{array}$ & 0.199 & $\begin{array}{l}0.021 ; \\
0.360\end{array}$ & 0.023 & 0.020 & Supported & 0.319 & 0.202 \\
\hline $\mathrm{H} 2$ & $\begin{array}{l}\text { Controlled Motivation } \rightarrow \\
\text { PEBs }\end{array}$ & 0.057 & $\begin{array}{l}-0.143 ; \\
0.259\end{array}$ & 0.586 & 0.002 & $\begin{array}{l}\text { Not } \\
\text { unported }\end{array}$ & & \\
\hline H3 & $\begin{array}{l}\text { GHRM practices } \rightarrow \\
\text { PEBs }\end{array}$ & 0.329 & $\begin{array}{l}0.201 \\
0.468\end{array}$ & 0.000 & 0.105 & Supported & & \\
\hline $\mathrm{H} 4$ & $\begin{array}{l}\text { Autonomous Motivation } \\
\text { X GHRM Practices } \rightarrow \\
\text { PEBs }\end{array}$ & 0.166 & $\begin{array}{l}0.013 \\
0.309\end{array}$ & 0.027 & 0.023 & Supported & & \\
\hline H5 & $\begin{array}{l}\text { Controlled Motivation X } \\
\text { GHRM Practices } \rightarrow \\
\text { PEBs }\end{array}$ & -0.020 & $\begin{array}{l}-0.264 ; \\
0.147\end{array}$ & 0.841 & 0.000 & $\begin{array}{c}\text { Not } \\
\text { Supported }\end{array}$ & & \\
\hline NA & Age* $^{*}$ PEBs & -0.012 & $\begin{array}{l}-0.227 \\
0.237\end{array}$ & 0.918 & 0.000 & $\begin{array}{c}\text { Not } \\
\text { Supported }\end{array}$ & & \\
\hline NA & $\begin{array}{l}\text { Education Attainment* } \\
\rightarrow \text { PEBs }\end{array}$ & 0.005 & $\begin{array}{l}-0.093 \\
0.093\end{array}$ & 0.917 & 0.000 & $\begin{array}{l}\text { Not } \\
\text { Supported }\end{array}$ & & \\
\hline NA & Experience* $\rightarrow$ PEBs & 0.076 & $\begin{array}{l}-0.158 \\
0.296\end{array}$ & 0.518 & 0.001 & $\begin{array}{l}\text { Not } \\
\text { Supported }\end{array}$ & & \\
\hline
\end{tabular}

Note: * (Control Variables); NA (Not Applicable); BCA CI (bias-corrected accelerate confidence interval)

Table 5. Assessment of Nonlinear Effects

\begin{tabular}{lcccc}
\hline \multicolumn{1}{c}{ Nonlinear relationship } & Beta & 97.5\% BCA CI & p-value & $\mathbf{f}^{2}$ \\
\hline Quadratic Autonomous Motivation $\rightarrow$ PEBs & 0.064 & $-0.009 ; 0.154$ & 0.139 & 0.008 \\
Quadratic Controlled Motivation $\rightarrow$ PEBs & -0.073 & $-0.160 ; 0.017$ & 0.109 & 0.011 \\
Quadratic GHRM Practices $\rightarrow$ PEBs & 0.009 & $-0.084 ; 0.102$ & 0.852 & 0.000 \\
\hline
\end{tabular}

Note: BCA CI (bias-corrected accelerate confidence interval)

Table 6. Results of Unobserved Heterogeneity Test 


\begin{tabular}{lccc}
\hline \multicolumn{1}{c}{ Criteria } & Segment 1 & Segment 2 & Segment 3 \\
\hline AIC (Akaike's Information Criterion) & 836.185 & 797.14 & $\mathbf{7 6 5 . 1 0 4}$ \\
AIC3 (Modified AIC with Factor 3) & 845.185 & 816.14 & $\mathbf{7 9 4 . 1 0 4}$ \\
AIC4 (Modified AIC with Factor 4) & 854.185 & 835.14 & $\mathbf{8 2 3 . 1 0 4}$ \\
BIC (Bayesian Information Criteria) & 870.458 & $\mathbf{8 6 9 . 4 9 5}$ & 875.54 \\
CAIC (Consistent AIC) & $\mathbf{8 7 9 . 4 5 8}$ & 888.495 & 904.54 \\
HQ (Hannan Quinn Criterion) & 849.852 & 825.992 & $\mathbf{8 0 9 . 1 4 1}$ \\
MDL5 (Minimum Description Length with Factor 5) & $\mathbf{1 , 0 7 9 . 5 5}$ & $1,310.91$ & $1,549.29$ \\
LnL (LogLikelihood) & -409.093 & -379.57 & $\mathbf{- 3 5 3 . 5 5 2}$ \\
EN (Entropy Statistic (Normed)) & NA & 0.276 & 0.474 \\
NFI (Non-Fuzzy Index) & NA & 0.316 & 0.451 \\
NEC (Normalized Entropy Criterion) & NA & 241.226 & 175.142 \\
\hline
\end{tabular}

Note: NA (Not Applicable); numbers in bold indicate the best outcome per segment criterion retention

\section{Figures}

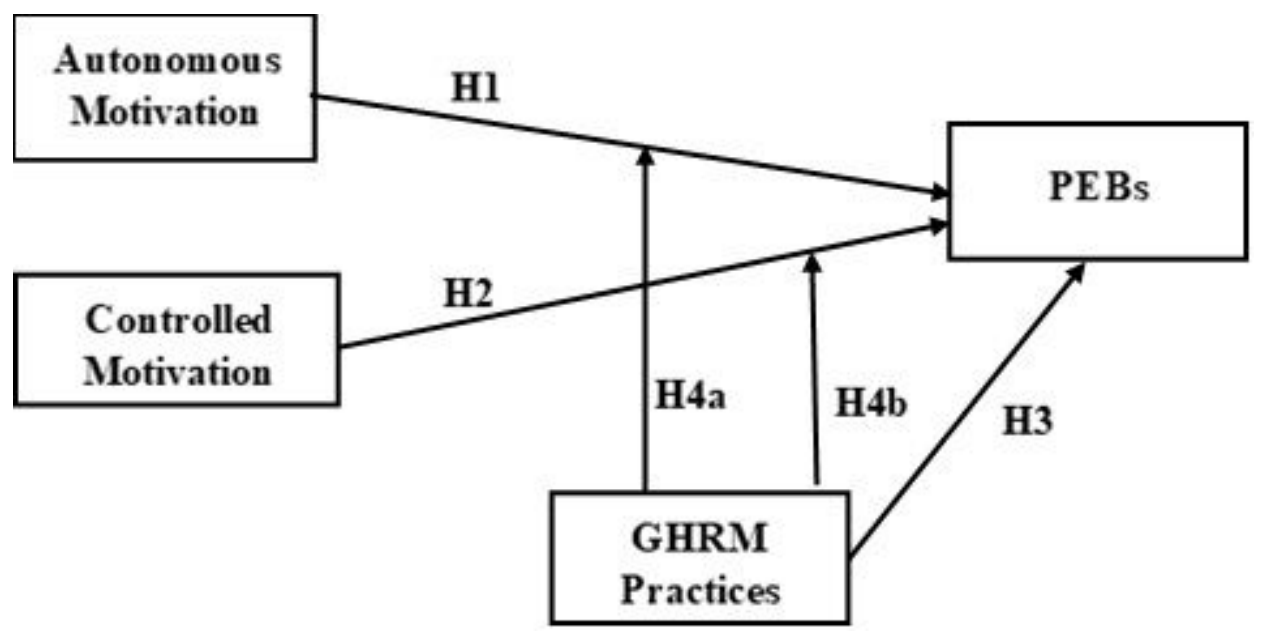

Figure 1

Conceptual Model 


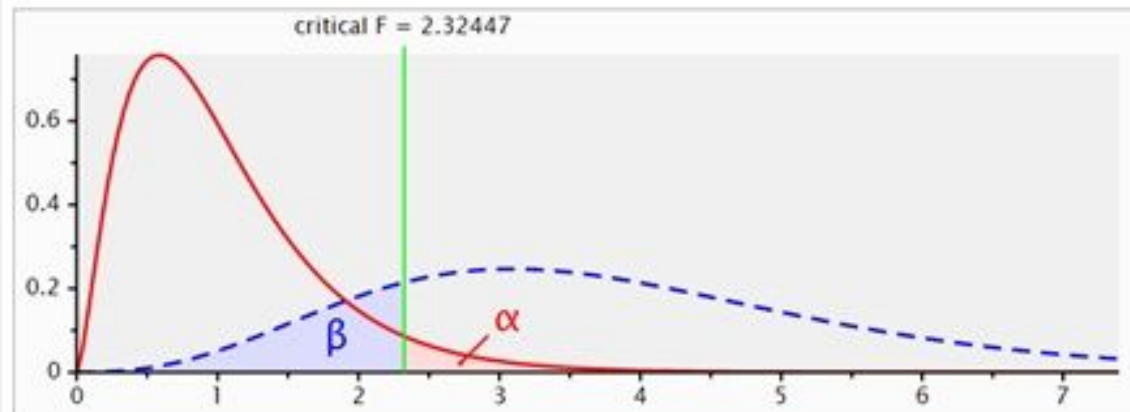

Test family

F tests

Statistical test

Type of power analysis

A priori: Compute required sample size - given $\alpha$, power, and effect size

Input Parameters Determine $=>$

\begin{tabular}{|c|c|}
\hline Effect size $f^{2}$ & 0.15 \\
\hline$\alpha$ err prob & 0.05 \\
\hline (1- $\beta$ err prob) & 0.80 \\
\hline sted predictors & 5 \\
\hline er of predictors & 8 \\
\hline
\end{tabular}

Output Parameters

Noncentrality parameter $\lambda$

Critical F

Numerator df

Denominator of

Number of tested predictors

Total number of predictors

\section{$\mathrm{X}-\mathrm{Y}$ plot for a range of values Calculate}

\section{Figure 2}

Results of G-Power Analysis

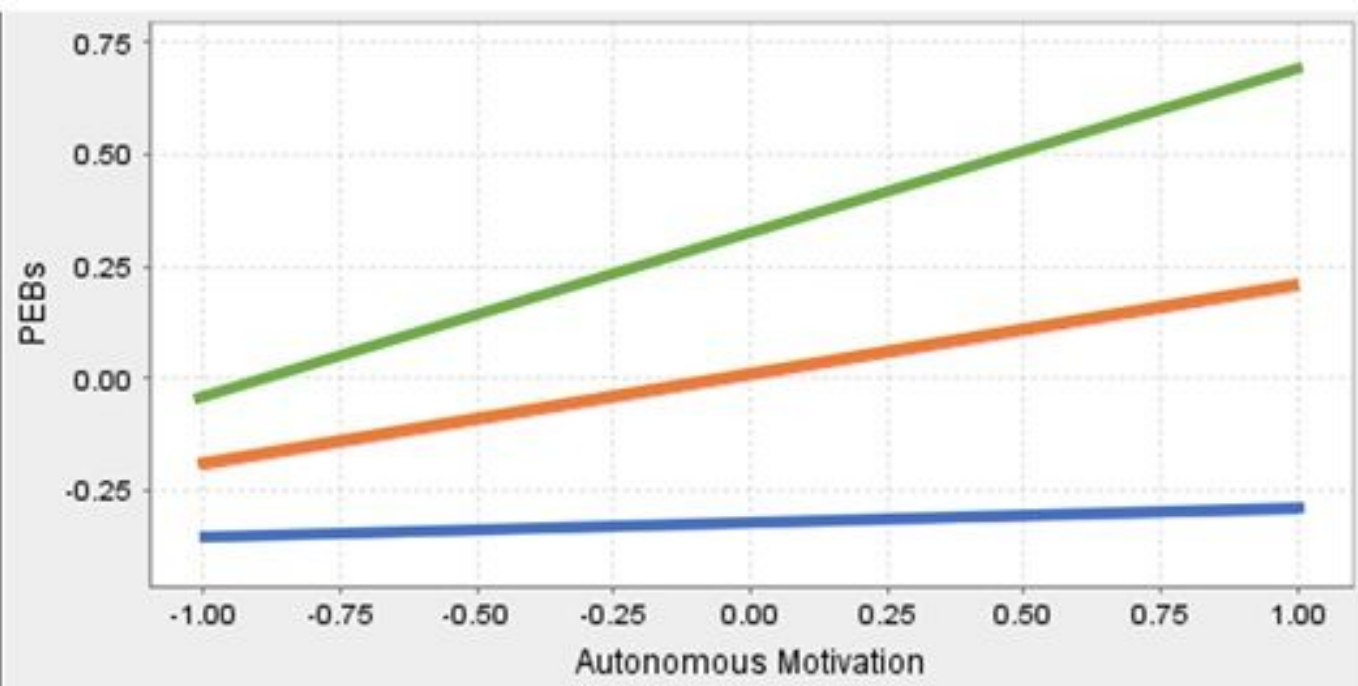

GHRM at $-1 S D=$ GHRM at Mean - GHRM at $+1 S D$

\section{Figure 3}

